\title{
A Historical Evaluation of Anthropogenic Impact in Coastal Ecosystems by Geochemical Signatures
}

\author{
Soraya M. Patchineelam, ${ }^{*}, a$ Christian J. Sanders, ${ }^{b}$ Joseph M. Smoak, ${ }^{c}$ \\ Rafaela C. Zem, ${ }^{a}$ Gustavo Oliveira $^{b}$ and Sambasiva R. Patchineelam ${ }^{b}$
}

\author{
${ }^{a}$ Centro de Estudos do Mar, Universidade Federal do Paraná, 83255-971 Pontal-PR, Brazil \\ ${ }^{b}$ Departamento de Geoquímica, Universidade Federal de Fluminense, 24020-141 Niterói-RJ, Brazil \\ ${ }^{c}$ Environmental Science, University of South Florida, 3370-000 St. Petersburg-FL, USA
}

\begin{abstract}
Indicadores geoquímicos de atividades antropogênicas foram usados como suporte para a datação de sedimentos de áreas costeiras por ${ }^{210} \mathrm{~Pb}$ (Laguna Guarapina, Saco da Marambaia e dados publicados na Baía de Guaratuba). As taxas de sedimentação estimadas foram 1,4 \pm 0,27, 6,1 $\pm 0,54$ e 4,7 \pm 0,21 mm/ano, respectivamente. Na Laguna Guarapina, um aumento na concentração da matéria orgânica foi correlacionado com a construção de um canal artificial na década de 1950. No Saco da Marambaia as modificações temporais na granulometria e concentrações de metais pesados corresponderam ao desvio hidrológico na década de 1950 e ao começo de atividades industriais na década de 1960 . Na Baía Guaratuba um pico de ${ }^{137} \mathrm{Cs}$ relacionado a 1963, enquanto os fluxos de $\mathrm{Hg}$ foram correlacionados com atividades humanas dentro da bacia de drenagem, como a construção de reservatórios e intensificação de práticas agrícolas desde a década de 1960.

Anthropogenic activities in Brazilian coastal areas were successfully used as a support for ${ }^{210} \mathrm{~Pb}$ dating (Guarapina Lagoon, Marambaia Sound and data previously published on Guaratuba Bay). The calculated ${ }^{210} \mathrm{~Pb}$ sedimentation rates were $1.4 \pm 0.27,6.1 \pm 0.54$ and $4.7 \pm 0.21 \mathrm{~mm} /$ year, respectively. In the Guarapina Lagoon, an increase in the organic matter concentration was well correlated with a construction of an artificial channel in the 1950's. In Marambaia Sound, temporal changes in grain-size and heavy metal concentrations corresponded to hydrological diversions in the 1950's and the beginning of industrial activities since the 1960's. In Guaratuba Bay, a 1963 ${ }^{137} \mathrm{Cs}$ fallout peak was found and $\mathrm{Hg}$ fluxes throughout the sediment profile that were correlated with human activities within the drainage basin, such as building of reservoirs and intensification of agricultural practices since the 1960's.
\end{abstract}

Keywords: ${ }^{210} \mathrm{~Pb}$ geochronology, metals, sediment accumulation rates, Brazilian geochemical signatures

\section{Introduction}

Geochemical studies of recent processes are essential in evaluating historical environmental changes that have been taking place since the beginning of the twentieth century. Since the 1980's environmental management and in turn, its control has become more rigid due to the recent anthropogenic impacts. Within the international debate over the results and efficiency of the implementation of needed actions, studies on geochemical processes have played an important role in evaluating degradation on relevant time scale. As environmental alterations may be registered in the

*e-mail: geosam@vm.uff.br substrate of estuarine sediments, changes in grain size as well as heavy metal concentration in sediment cores may be used to evaluate human impact in estuaries. ${ }^{1}$

Dating sediments through ${ }^{210} \mathrm{~Pb}$ (half life $=22.3$ years) allow calculating sedimentation rates for $c a$. 100 years. A list of chemical properties of the radionuclide ${ }^{210} \mathrm{~Pb}$ and of its parent in decay series of ${ }^{238} \mathrm{U}$ favors its use in the application in recent sediment cycles. ${ }^{2}$ It has been successfully used in lakes ${ }^{3-7}$ estuaries, ${ }^{7-12}$ inner continental plataforms ${ }^{13-15}$ and mangrove ecosystems. ${ }^{15-19}{ }^{210} \mathrm{~Pb}$ geochronologies are especially significant when confirmed by anthropogenic signatures in sediment profiles. From the beginning of the second half of the twentieth century, when industrial and urban development were intensified, various ecosystems 
along the Brazilian coast have been highly impacted. These alterations have been registered within the profile of wellpreserved sediments.

This work attempts to evaluate historical impacts of human activity along the south-southeastern coast of Brazil. The principal aim is to correlate the anthropogenic effects registered in the sediments of three ecosystems: Guarapina Lagoon and Marambaia Sound, Rio de Janeiro State and Guaratuba Bay, Paraná State. To achieve this objective, changes in grain size, organic material and metal concentrations as well as rates of sedimentation using ${ }^{210} \mathrm{~Pb}$ techniques were determined in sediment columns.

Study area

The three ecosystems in this study have been suffering different levels of human induced alterations since the second half of the twentieth century. (A) Guarapina lagoon, located on the east coast of Rio de Janeiro State (22 $75^{\circ}$ 'S, $42^{\circ} 44^{\prime} \mathrm{W}$ ) (Figure S1, A, Supplementary Information, SI), showed little anthropogenic impact. In the 1950's, the state government opened a channel connecting the lagoon to the Atlantic Ocean. This channel was built to allow ocean water to circulate, avoiding health risks associated with malaria; (B) Marambaia Sound, located on the west coast of Rio de Janeiro in Sepetiba Bay (23 $02^{\prime} \mathrm{W}$ and $23^{\circ} 04^{\prime} \mathrm{S}$ ) (Figure S1, C, SI), is situated on the southern coast of Rio de Janeiro State. This area has been struck with significant alterations during previous few decades, such as industrial development, establishment of ports, and a sharp population increase. At the same time, the drainage basin that feeds fresh water to the bay has also been beset with modifications associated with human development. Because of these reasons, Marambaia Sound can be considered the most impacted by anthropogenic activities of the three ecosystems mentioned. (C) Guaratuba Bay, located in southern coast of Paraná State (25 $50^{\circ} \mathrm{S}, 48^{\circ} 28^{\prime} \mathrm{W}$ ) (Figure S1, C, SI), anthropogenic signatures were detected. The source of this impact may come from the development of agricultural activities and hydrological modifications within the drainage basin, such as dam construction.

\section{Experimental}

Sediment cores were collected, one in the center of Guarapina Lagoon, another in the interior of Guaratuba Bay and a third in Marambaia Sound (Figure S1, SI). Acrylic tubes, $50 \mathrm{~cm}$ in length and $7 \mathrm{~cm}$ internal diameter were used. The sediment core from Guarapina Lagoon was sliced in $1 \mathrm{~cm}$ until $2 \mathrm{~cm}$ and $2 \mathrm{~cm}$ intervals until 30 $\mathrm{cm}$. The core from Guaratuba Bay was sectioned in $2 \mathrm{~cm}$

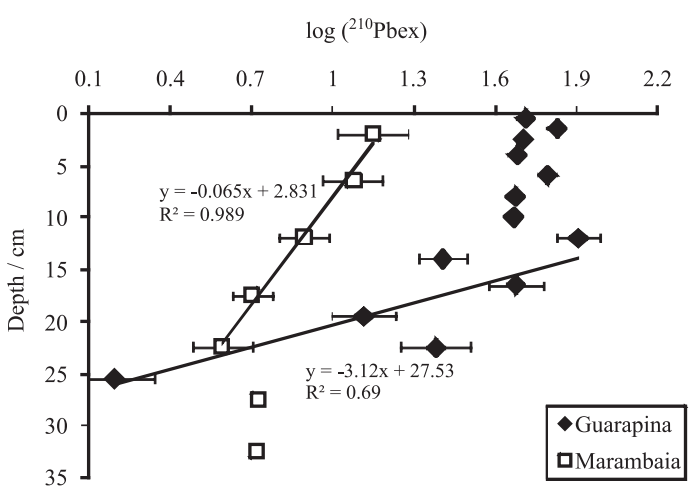

Figure 1. Excess ${ }^{210} \mathrm{~Pb}$ profiles.

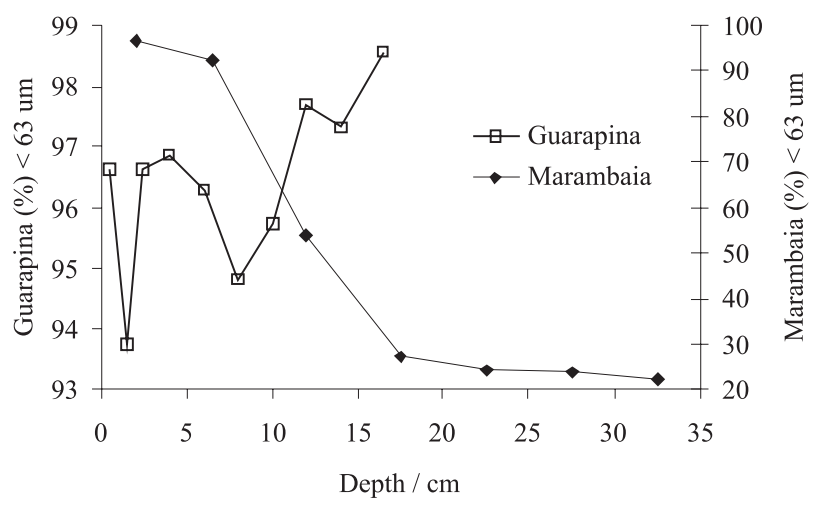

Figure 2. Mud content profiles.

intervals until the $10 \mathrm{~cm}$ mark, $3 \mathrm{~cm}$ intervals until $25 \mathrm{~cm}$ mark and $5 \mathrm{~cm}$ intervals for the rest of the core. For the Marambaia Sound core, the same procedure was used until the $6 \mathrm{~cm}$ mark, from 6 until $15 \mathrm{~cm}$ the intervals were 3 $\mathrm{cm}$ and $5 \mathrm{~cm}$ from 15 to 30 . Grain-size determination was carried out in all samples as well as organic material and carbonate percentages. ${ }^{20}$

After sectioned, samples were placed in plastic bags, taken to the laboratory, homogenized, weighed and placed in Petri dishes for 3 weeks to attain secular equilibrium. Radionuclide activity was determined using a Canberra coaxil detector "extended range" hyperpure Ge $(40 \%$ efficiency). This detector was coupled to a multichannel analyzer with counting times that were between 60.000 and $120.000 \mathrm{~s}$ for all samples. The resolution for the equipment was 1.68 to $122.09 \mathrm{keV}$ and 2.1 to $1.33 \mathrm{meV}$. Detection limit calculated by the detectors software was $0.03 \mathrm{~Bq} \mathrm{~kg}^{-1}$. Counting errors for the peak area of the $295.2 \mathrm{keV}$ varied between 9.6 and $22.6 \%, 351.9 \mathrm{keV}$ varied 5.5 between $13.5 \%$. Counting errors for the $351.9 \mathrm{keV}$ peak were substantially less and therefore were used to determine ${ }^{226} \mathrm{Ra}$. Counting errors for the $46.5 \mathrm{keV}$ peak varied between 6.6 and $24.5 \%$, used to determine ${ }^{210} \mathrm{~Pb}$.

An efficiency curve was obtained by measuring and analyzing a certified standard cocktail of radionuclides certified 
by IRD - Instituto de Radioproteção e Dosimetria. Correction for self-absorption were done by calculating a source of ${ }^{210} \mathrm{~Pb}$ with a known activity (specific activity $=1.5 \mathrm{~Bq}$ ), first over an empty container then over each sample. These measurements were done for $2 \mathrm{~min} .{ }^{21}$ Each sample contained a self-absorption factor that was incorporated in the final tally of the total ${ }^{210} \mathrm{~Pb}$. Samples were then dried at $60{ }^{\circ} \mathrm{C}$ until a constant weight was reached. Porosity was calculated with the method outlined in Baskaran and Naidu. ${ }^{22}$

To validate the ${ }^{210} \mathrm{~Pb}$ sediment dating method, different analyses were performed according to specific anthropogenic occurrences in areas examined. Granulometric measurements (through wet sieving) and organic material (LOI), the difference between weight before combustion and after combustion at $450{ }^{\circ} \mathrm{C}$ for $24 \mathrm{~h}$, were measured in all sediment cores.

As for the Marambaia Sound, sample analyses of $\mathrm{Zn}, \mathrm{Cd}$ and $\mathrm{Cu}$ were performed. For metal extraction, approximately 1 to $2 \mathrm{~g}$ of dried sediment were ground in an agith mortal and pestle. The addition of fluoric and nitric acid, 3:1 respectively, was used for extraction. Samples were then recuperated with $\mathrm{HNO}_{3}$ and made up to $25 \mathrm{~mL}$ in volumetric bottle. The extracts were then taken to a Perkin Elmer, model Analist 300, atomic absorption spectrometer for analyses. Replicates were analyzed for quality assurance. Error bars represent the standard deviation. For the Guaratuba Bay samples, Hg concentration was measured. These concentrations were measured by taking $1.0 \mathrm{~g}$ of dry $\left(50^{\circ} \mathrm{C}\right.$ for $\left.48 \mathrm{~h}\right)$, ground sediment from each sample. Digestion was done using aqua regia $50 \%$ on a sand bath at $70{ }^{\circ} \mathrm{C}$ for $1 \mathrm{~h}$. Total $\mathrm{Hg}$ was analyzed by cold vapor atomic absorption spectrometry (Bacharach Coleman, model 50D). ${ }^{23}$ The limit of detection ( 3 times the standard deviation of the standards) was $4 \mathrm{ng} \mathrm{g}^{-1}$. The error was calibrated with reference sediments PACS-2 and NIST SEM-2794, which resulted in the recuperation of $83 \pm 6 \%$ and $96 \pm 10 \%$, respectively.

\section{Results and Discussion}

\section{Guarapina Lagoon}

The sedimentation rate was calculated to be $1.4 \pm 0.27 \mathrm{~mm} /$ year through the excess ${ }^{210} \mathrm{~Pb}$ method
(Table 1), after a mixed layer and backgrounds were eliminated (Figure 1). It is also fair to consider sedimentation rates determined by metal contamination ${ }^{24}$ of $3.4 \mathrm{~mm} / \mathrm{year}$ and by nutrient loads ${ }^{25}$ of $2.7 \mathrm{~mm} /$ year. The latter author mentioned also use of the excess ${ }^{210} \mathrm{~Pb}$ method, through alpha measurements. These differences in rates may be due to spatial factors in the sediment accumulation rate (SAR) that occur within al lagoon-estuarine systems. ${ }^{26}$

The percentage of fine-grained sediment (silt and clay) remained relatively high (>90\%), decreasing slightly towards the surface (Figure 2), while the organic material percentage varied between 15 and $25 \%$ (Figure 3 ). The values are similar to those found in other studies of this area. ${ }^{26}$ This discussion is made keeping in mind the limitations of evaluating changes inside the mixing layer.

In relation to the organic matter content in the sediment, the opening of the channel that connects the Atlantic Ocean to Guarapina Lagoon was dug out approximately fifty years ago, allowing oxygen rich ocean water to enter the lagoon. Before 1950 Guarapina Lagoon could have been considered a swamp, having low levels of oxygen. With these probably low levels of oxygen, organic material would have decomposed at a lower rate than at the present time. Applying the sedimentation rate found in this study, the first layer with higher organic material concentrations go back approximately 50 years, after the mixed layer is subtracted from the profile $(\mathrm{d}=7.5 \mathrm{~cm} ; \mathrm{t}=50$ years $)$, giving a sedimentation rate of $1.5 \mathrm{~mm} /$ year. This chronology supports the SAR taken with ${ }^{210} \mathrm{~Pb}$ dating. This time period agrees with when the channel was opened, during the 1950's (Table 2).

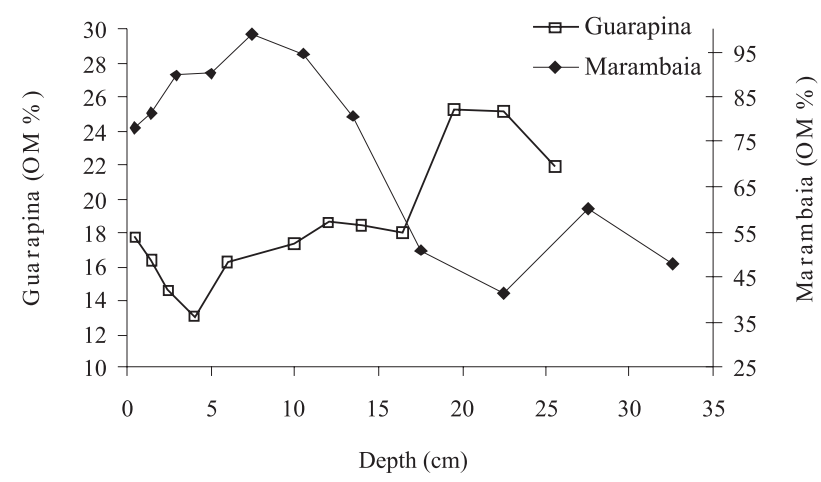

Figure 3. Organic matter content profiles.

Table 1. Sediment accumulation rates

\begin{tabular}{lccc}
\hline Study area & ${ }^{210} \mathrm{~Pb}(\mathrm{SAR}$ 's) & Anthropogenic (SAR's) & Source \\
\hline Guarapina & $1.4 \mathrm{~mm} / \mathrm{year}$ & $1.5 \mathrm{~mm} / \mathrm{year}$ & This study \\
Guaratuba & $6.2 \mathrm{~mm} / \mathrm{year}$ & $5.4 \mathrm{~mm} / \mathrm{year}$ & Sanders et al. ${ }^{39} 2006$ \\
Marambaia & $4.7 \mathrm{~mm} / \mathrm{year}$ & $>3.8 \mathrm{~mm} / \mathrm{year}$ & This study \\
\hline
\end{tabular}


Table 2. Historical events in the areas studied

\begin{tabular}{|c|c|c|c|c|c|}
\hline Location & Depth / cm & Changes in the sedimentary profile & Year & Event & Period \\
\hline Guarapina & $16-20$ & Decrease in organic material & 1950 & Opening of channel & 1950 to present \\
\hline \multicolumn{6}{|l|}{ Guaratuba } \\
\hline & 16 & $\begin{array}{l}\text { Increase in } \mathrm{OM} \text { and of fine grain } \\
\text { sediment percentage }\end{array}$ & $1952-1984$ & Construction of damns & 1950 to present \\
\hline & 16 & $\mathrm{Hg}$ enrichment & 1950’s & Begining of agricultural activity & 1950 's to present \\
\hline & 22.5 & Maximum ${ }^{137} \mathrm{Cs}$ activity & 1963 & Environmental control measures & 1954 to the 1970 's \\
\hline \multicolumn{6}{|l|}{ Marombaia } \\
\hline & $17.5-6.5$ & $\begin{array}{l}\text { Increase in the percentage of fine } \\
\text { grain sediment }\end{array}$ & $1952-1984$ & $\begin{array}{l}\text { Transposition of the Paraiba do } \\
\text { Su river }\end{array}$ & 1950’s \\
\hline & 10.5 & Begining of positive values of $\mathrm{Cd}$ & 1973 & $\begin{array}{l}\text { Beginning of Cadmium production } \\
\text { by the Zinc Smelter (Ingá) }\end{array}$ & 1974 \\
\hline & 7.5 & Maximum metal concentration & 1970’s & Environmental control measures & 1980 's to present \\
\hline
\end{tabular}

\section{Marambaia Sound}

Sedimentation rates were calculated to be $4.7 \pm 0.21 \mathrm{~mm} /$ year after a mixed layer and backgrounds were eliminated (Figure 1). The fine-grained sediment profile demonstrated an abrupt inclination, going from $25 \%$ at the base of the core to more than $90 \%$ in the superficial layers (Figure 2). The maximum concentration can be seen at $7.5 \mathrm{~cm}$ depth level.

The grain size and metal profiles (Figure 3) registered two distinct events that may be associated to anthropogenic alterations in Sepetiba Bay, reaching Marambaia Sound. Temporal changes in grain-size profile began to become altered when the Marambaia Sound underwent the same increase in mud content observed in other areas of the Sepetiba Bay. ${ }^{27}$ According to the sedimentation rate calculated in this core, this change in grain-size profile took place approximately 43 years ago. This date, during the 1960's, coincides with the time period when channels in the drainage were constructed, connecting Sepetiba Bay to the Paraíba do Sul river (Table 2). This type of construction is known to cause an increase in fine grain sediment discharge, according to the model developed by Molisani. ${ }^{28}$ This higher fine grain sediment flux into the Sepetiba Bay most likely made its way to the Marambaia Sound, as noted sediment profile of this core.

The coastal region of Sepetiba Bay, has been experiencing an exponential population growth, being induced by industrialization and urbanization. ${ }^{29-33}$ Industries established in 1966, produced Zn ingots, until the end of the 1990 's. During this time, this industry released significant quantities of $\mathrm{Zn}$ and $\mathrm{Cd}$ as evidenced in the sediment surrounding the area (Table 2). The peak concentrations of these metals in the cores taken at Marambaia Sound were registered at $7.5 \mathrm{~cm}$ (Figure 4). This peak concentration can be attributed to the steps that were taken to reduce the amount of contamination caused by the discharge of these
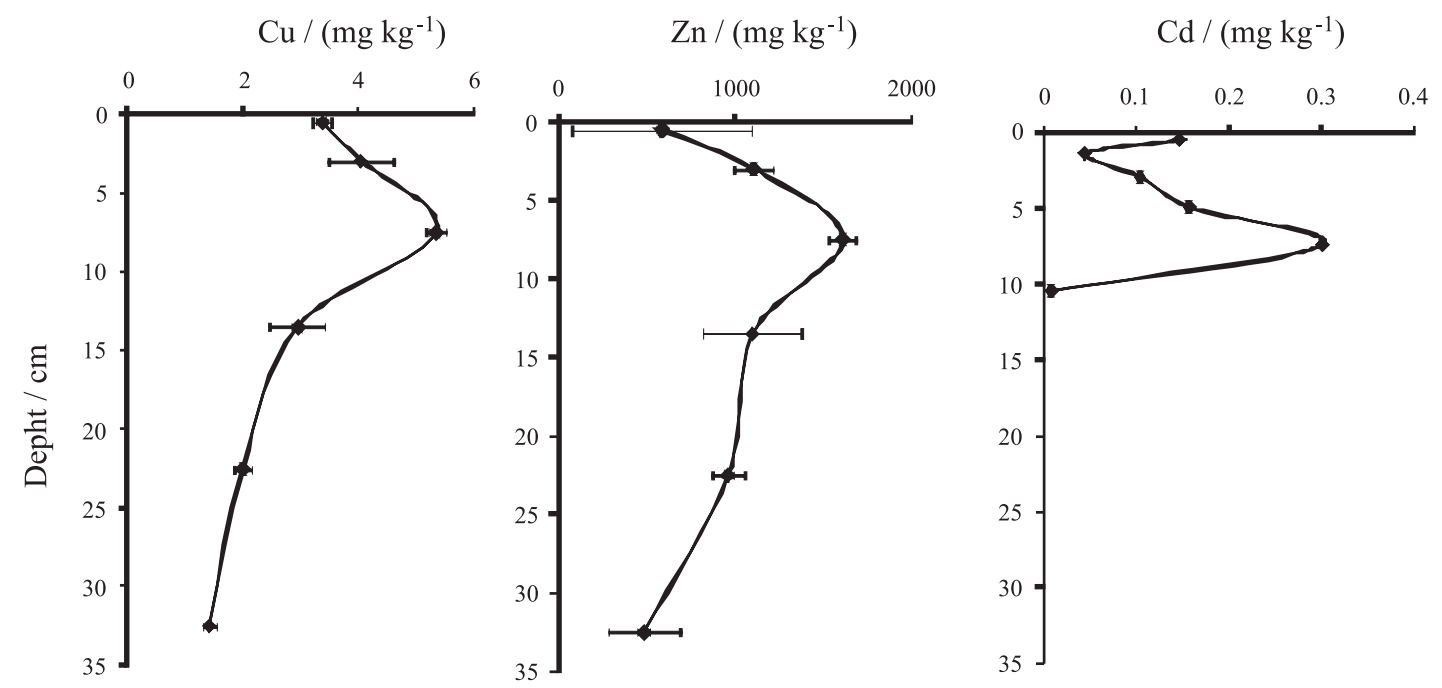

Figure 4. Marambaia sound metal profiles. 
metals. From these peaks, a sediment accumulation rate of 3.8 may gathered (Table 1).

While $\mathrm{Zn}$ and $\mathrm{Cd}$ showed an anthropogenic point source in Marambaia Sound sediments, $\mathrm{Cu}$ reaches the bay through diffuse sources. ${ }^{34}$ The values found for $\mathrm{Cd}$ are within the range detected by Leitão, ${ }^{35}$ while the $\mathrm{Zn}$ values were greater than those reported by the same author, in reference to superficial sediments in Marambaia Sound. The $\mathrm{Cu}$ concentrations are somewhat less than those found by Rodrigues ${ }^{36}$ in superficial sediments of the mouth of the São Francisco channel, most likely due to the distance of the principal sources $\mathrm{Cu}$, located at the Northeast of Sepetiba Bay.

The variation in $\mathrm{Zn}$ concentration may represent the time period when this metal was highly industrialized in this bay. A similar tendency was found in a core at the tip of Madeira Island. ${ }^{37}$ Moreover, the peak concentrations of metals at the $7.5 \mathrm{~cm}$ depth were probably generated by the increasing amount of fine grained sediment, since the concentrations of $\mathrm{Cd}$ and $\mathrm{Cu}$ along the core are too small to represent the height of industrialization in this bay, thereby not registering anthropogenic peaks in the concentration of these metals. ${ }^{38}$

\section{Guaratuba Bay, PR}

The sedimentation rate in the sampling site was calculated to be near $6.1 \pm 0.54 \mathrm{~mm} /$ year through the excess ${ }^{210} \mathrm{~Pb}$ dating method, while the presence of a welldefined ${ }^{137} \mathrm{Cs}$ peak, at the $21.5 \mathrm{~cm}$ depth, made a SAR calculation of $5.2 \mathrm{~mm} /$ year possible (Table 1). Increasing $\mathrm{Hg}$ fluxes were also observed by Sanders et al., ${ }^{39} 2006$. According to Godoy et al., ${ }^{6}$ 2002, this tendency in $\mathrm{Hg}$ fluxes is an indication of increasing agricultural activity, which have been used in fertilizers that have $\mathrm{Hg}$ as a subproduct. Also, the decrease in the sediment grain-size towards the top of the core and an increase of organic matter concentration since the 1950's, are probably related to the construction of dams and the intensification of agricultural activity in the basin (Table 2). Dams are recognized globally as sediment traps, especially coarse grains, at the same time agricultural activity in the drainage basin below the dam site is known to increase organic matter concentration in soil and thus in runoff sediments.

\section{Conclusions}

Geochemical signatures imprinted in recent sediments in ecosystems along the Brazilian coast, reflect the anthropogenic impact that occurred in the second half of the $20^{\text {th }}$ century. Sediment dating through excess ${ }^{210} \mathrm{~Pb}$ has proved to be a useful tool for studying recent sedimental and geochemical processes in coastal areas. In Guarapina Lagoon, for example, a temporal variation of the organic matter concentration was well correlated to the opening of a channel in the 1950's, connecting the lagoon to the Atlantic Ocean. In Marambaia Sound, Sepetiba Bay, variations in grain size and metal concentrations correspond, respectively, to the anthropogenic influences such as the construction of channels in the 1950's and the establishment of industrial activities since the 1980's within the drainage basin. In Guaratuba Bay, variation in grain size and in $\mathrm{Hg}$ concentration corresponds to anthropogenic influences in the drainage basin, such as the construction of dams and the intensification of agricultural activities. Temporal analyses of these changes along the sediment column have shown to be a good option for verifying geochronology through ${ }^{210} \mathrm{~Pb}$ in locations that have been impacted by anthropogenic activities.

\section{Supplementary Information}

Supplementary data are available free of charge at http://jbcs.sbq.org.br, as PDF file.

\section{Acknowledgments}

This work was funded by the Conselho Nacional de Desenvolvimento Científico e Tecnológico Brazil (CNPq). J. M. S. was supported by Fulbright and C. J. S. from FAPERJ grant (E-26/101.952/2009).

\section{References}

1. Sanders, C. J.; Smoak, J. M.; Naidu, A. S.; Patchineelam, S. R.; Environ. Earth Sci. 2010, 60, 1291.

2. Koide, M.; Bruland, K. W.; Goldberg, E., D.; Earth Planet. Sci. Lett. 1973, 11, 407.

3. Oldfield, F.; Appleby, P. G.; Chem. Geol. 1984, 44, 67.

4. Turner, L. J.; Delorme L. D.; Environ. Geol. 1996, $28,78$.

5. Mecray, E. L.; King J. W.; Appleby, P. G.; Hunt, A. S.; Water, Air, Soil Pollut. 2001, 125, 201.

6. Godoy, J. M.; Padovani, C. R.; Gaimarães, J. R. D.; Pereira, J. C. A.; Vieira, L. M.; Carvalho, Z. L.; Galdino, S.; J. Braz. Chem. Soc. 2002, 13, 71.

7. Godoy, J. M.; Moreira, I.; Oreira, I.; Bragança, M. J.; Wanderley, C.; Mendes, L. D.; J. Radioanal. Nucl. Chem. 1998, 227, 157.

8. Fuller, C. C.; Van Green, A.; Baskaran, M.; Anima, R.; Mar. Chem. 1999, 64, 7.

9. Patchineelam, S. M.; Kjerfve, B.; Gardner, L. R.; Mar. Geol. 1999. $162,133$. 
10. Ram, A.; Rokade, M. A.; Borole, D.; Zingde, M. D.; Mar. Pollut. Bull. 2003, 46, 846.

11. Plater, A. J.; Appleby, P. G.; Estuar. Coast. Shelf Sci. 2004, 60, 179.

12. Nitrouer, C. A.; Sternberg, R. W.; Carpenter, R.; Bennett, J. T.; Mar. Geol. 1979, 31, 297.

13. Somauajulu, B. L. K.; Bhushan, R.; Ashish, S.; Burr, G. S.; Jull, A. J. T.; Sci. Total Environ. 1999, 237/238, 429.

14. Santschi, P. H.; Guo, L.; Asbill, S.; Allison, M.; Kepple, A. B.; Mar. Chem. 2001, 73, 125.

15. Lynch, J. C.; Meriwether, J. R.; McKee, B. A.; Vera-Herrera, F.; Twilley, R. R.; Estuaries 1989, 12, 284.

16. Smoak, J. M.; Patchineelam, S. R.; Mangroves and Salt Marshes 1999, 3, 17.

17. Walsh J. P.; Nittrouer C. A.; Mar. Geol. 2004, 208, 225.

18. Brunskill, G. J.; Zagorskis, I.; Pfitzne, J.; Ellison, J.; Cont. Shelf Res. 2004, 24, 2535.

19. Borges, A. C.; Sanders, C. J.; Machado, W.; Patchineelam, S. R.; Mar. Pollut. Bull. 2009, 58, 1750.

20. Suguio, K.; Introdução à Sedimentologia, Edgard Blucher: São Paulo, 1973, p. 316.

21. Cutshall, N. H.; Larsen, I. L.; Olsen. C. R.; Nucl. Instrum. Methods 1983, 206, 309.

22. Baskaran, M.; Naidu, A. S.; Geochim. Cosmochim. Acta 1995, 59, 4435.

23. Lacerda, L. D.; Goncalves G. O.; Mar. Chem. 2001, 76, 47.

24. Seeliger, U.; Lacerda, L. D.; Pfeiffer, W. C.; Patchineelam, S. R.; Metals in Coastal Environments of Latin America, Springer Verlag: Berlin, 1988, p. 65.

25. Knoppers, B. A.; Camourze Amourze, J. P.; Moreira-Turcq, P. F. In Environmental Geochemistry of Coastal Lagoons System (Série Geoquímica Ambiental, v. 6); Knoppers, B. A.; Abrão, J. J., eds., EDUFF: Rio de Janeiro State, Brazil, 1999.

26. Sanders, C. J.; Patchineelam, S. M.; Zem, R.; Patchineelam, S. R.; Oceanografia e Mudanças Globais, São Paulo: Braga, Elisabete de Santis, 2008, 1, 739.
27. Borges, H. V.; PhD Thesis, State University of New York, USA, 1998. (text available under request)

28. Machado, W.; Santelli, R. E.; Carvalho, M. F.; Molisani, M. M,; Barreto, R. C.; Lacerda, L. D.; J. Coastal Res. 2008, 24, 25.

29. Barcellos, C.; Lacerda, L. D.; Environ. Mon. Assess. 1994, 29 , 183.

30. Gomes, F. C.; Godoy, J. M.; Godoy, M. L. D. P.; de Carvalho, Z. L.; Lopes, R. T.; Sanchez-Cabeza, J. A.; de Lacerda, L. D.; Wasserman, J. C.; Mar. Pollut. Bull. 2009, 59, 123.

31. Lacerda, L. D.; Pfeiffer, W. C.; Fiszman, M.; Sci. Total Environ. 1987, 65, 163.

32. Lacerda, L.D.; Santelli, R.E.; Duursma, E.K.; Abrão, J.J., eds.; Facets of Environmental Geochemistry in Tropical and Subtropical Environments, Springer Verlag, Heidelberg, 2004.

33. Machado, W. ; Santelli, R. E.; Carvalho, M. F.; Molisani, M. M.; Barreto, R. C.; Lacerda, L. D.; J. Coast. Res. 2008, 24, 25.

34. Rees, J. G.; Breward, N.; Maddock, J.; Ferguson, A. J.; Williams, T, M.; Technical Report WC/98/30 Overseas Geology Series, Land-Ocean Contamination Study, NERC BGS Keyworth: Nottongham, 1998.

35. Japenga, J.; Wagenaar, W. J.; Salomons, W.; Lacerda L. D.; Patchineelam S. R.; Leitao, C. M.; Sci. Total Environ. 1988, 75, 249.

36. Rodrigues, P. W.; MSc Dissertation, Universidade Federal Fluminense, Brazil, 1990. (text available under request)

37. Barcellos, C.; Lacerda, L. D.; Environ. Monit. Assess. 1994, 29 , 183.

38. Brunskill, G. J.; Zagorskis, I.; Pfitzne, J.; Ellison, J.; Cont. Shelf Res. 2004, 24, 2535.

39. Sanders, C. J.; Santos, I. R.; Silva, E. V.; Patchineelam, S. M.; Mar. Pollut. Bull. 2006, 52, 1085.

Submitted: May 17, 2010

Published online: August 24, 2010 


\title{
A Historical Evaluation of Anthropogenic Impact in Coastal Ecosystems by Geochemical Signatures
}

\author{
Soraya M. Patchineelam, ${ }^{*}, a$ Christian J. Sanders, ${ }^{b}$ Joseph M. Smoak, ${ }^{c}$
}

Rafaela C. Zem, ${ }^{a}$ Gustavo Oliveira $^{b}$ and Sambasiva R. Patchineelam ${ }^{b}$

${ }^{a}$ Centro de Estudos do Mar, Universidade Federal do Paraná, 83255-971 Pontal-PR, Brazil

${ }^{b}$ Departamento de Geoquímica,Universidade Federal de Fluminense, 24020-141 Niterói-RJ, Brazil

${ }^{c}$ Environmental Science, University of South Florida, 3370-000 St. Petersburg-FL, USA

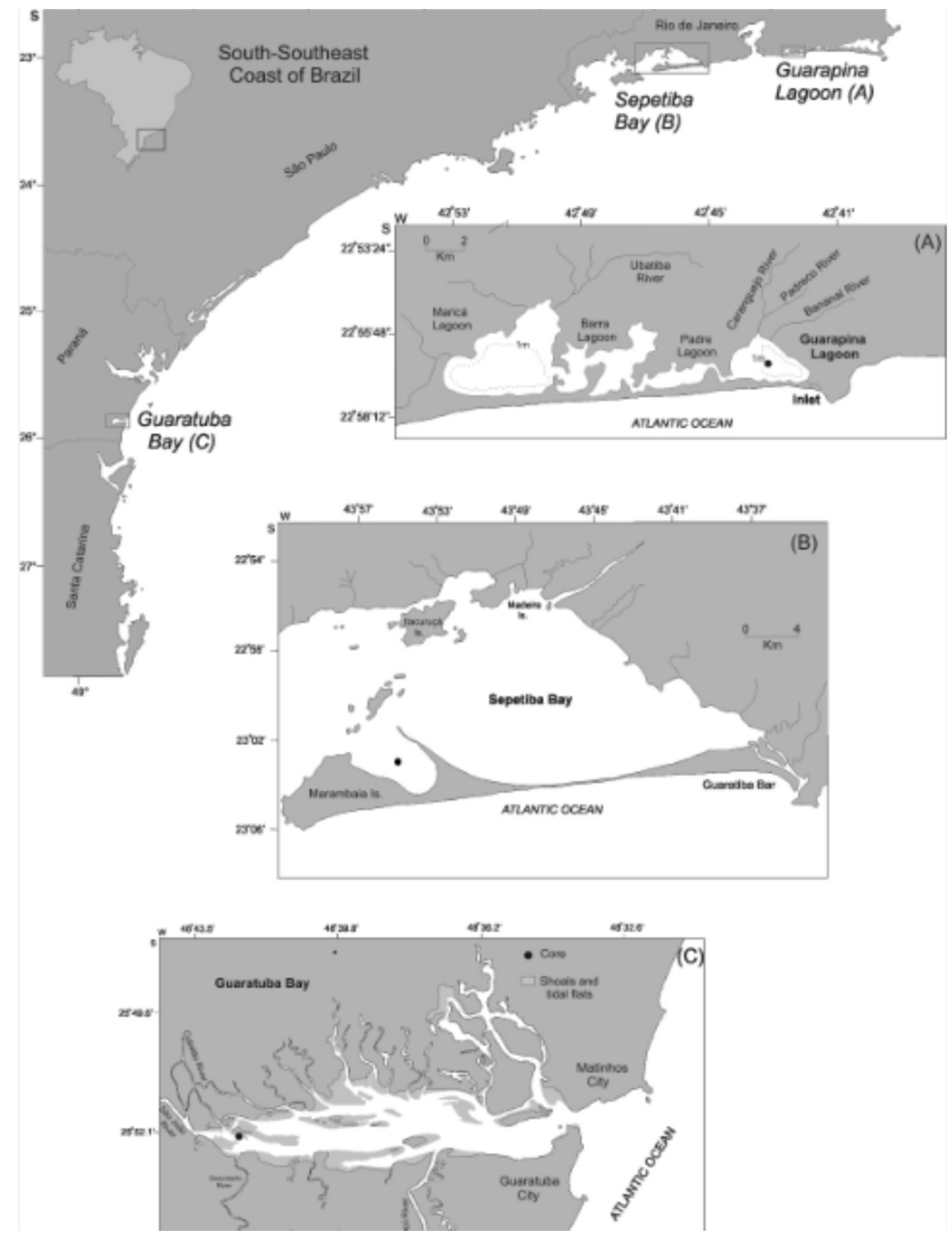

Figure S1. Study areas.

*e-mail: geosam@vm.uff.br 